\title{
Study of sol-gel derived di-ureasils doped with zinc triflate
}

\author{
S. C. Nunes ${ }^{\text {a }}$, V. de Zea Bermudez ${ }^{\text {a* }}$, M. M. Silva ${ }^{\text {b }}$, M. J. Smith ${ }^{\text {b }}$ E. Morales ${ }^{\text {c }}$, R. A. Sá

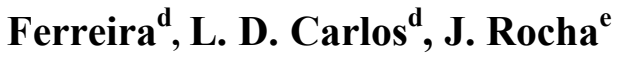 \\ ${ }^{a}$ Departamento de Química and CQ-VR, Universidade de Trás-os-Montes e Alto Douro \\ 5000-911 Vila Real, Portugal \\ ${ }^{\mathbf{b}}$ Departamento de Quimica, Universidade do Minho, Gualtar, 4710-057 Braga, Portugal \\ ${ }^{\mathfrak{c} I n s t i t u t o ~ d e ~ C i e n c i a ~ y ~ T e c n o l o g i ́ a ~ d e ~ P o l i ́ m e r o s ~(C S I C), ~ C a l l e ~ J u a n ~ d e ~ l a ~ C i e r v a ~ 3, ~} 28006$ Madrid, Spain \\ 'Departamento de Física and CICECO, Universidade de Aveiro, 3810-193 Aveiro, Portugal \\ ${ }^{\mathrm{e}}$ Departamento de Quimica and CICECO, Universidade de Aveiro, 3810-193 Aveiro, Portugal
}

\begin{abstract}
Zinc triflate $\left(\mathrm{Zn}\left(\mathrm{CF}_{3} \mathrm{SO}_{3}\right)_{2}\right)$-doped sol-gel derived di-urea cross-linked POE/siloxane ormolytes (designated as di-ureasils) with $\infty>n \geq 1$ (where the salt content is expressed as $n$, the molar ratio of oxyethylene moieties to $\mathrm{Zn}^{2+}$ ions) were investigated. The hybrids with $\mathrm{n} \geq$ 5 are entirely amorphous; those with $\mathrm{n}>10$ are thermally stable up to approximately $305^{\circ} \mathrm{C}$. The siliceous network of representative samples $(n=200$ and 10) is essentially composed of $(\mathrm{SiO})_{3} \mathrm{Si}\left(\mathrm{CH}_{2}\right)$ - environments and is thus highly branched. The distance between the structural units in samples with $200 \geq n \geq 10$ and $n \leq 7$ is 4.2 and $4.3 \AA$, respectively. The estimated interdomain distance is 11 and $13 \AA$ for xerogels with $200 \geq n \geq 20$ and $n \leq 10$, respectively. At $\mathrm{n}=1$ a crystalline $\mathrm{POE} / \mathrm{Zn}\left(\mathrm{CF}_{3} \mathrm{SO}_{3}\right)_{2}$ complex of unknown stoichiometry is formed. The conductivity maxima are located at $\mathrm{n}=60\left(3 \times 10^{-6} \mathrm{~S} \mathrm{~cm}^{-1}\right)$ and $\mathrm{n}=20\left(7 \times 10^{-5} \mathrm{~S} \mathrm{~cm}^{-1}\right)$ at 30 and $100^{\circ} \mathrm{C}$, respectively.
\end{abstract}

Keywords: POE/siloxane, di-ureasils, zinc triflate, ionic conductivity

\footnotetext{
${ }^{*}$ Corresponding author. Tel: +351-259-350253; Fax: +351-259-350480; E-mail address: vbermude@utad.pt
} 


\section{Introduction}

In the field of solid polymer electrolytes (SPEs) the hybrid concept [1], which is intimately associated with the sol-gel process [2-5], is one of the most attractive strategies that may be adopted to modify the architecture of poly(oxyethylene) (henceforth abbreviated as POE). In this domain the synthesis of POE/siloxane hybrid structures is achieved through the sol-gel strategy, with the objective of reducing the drawbacks of poor processability, a marked tendency to form crystalline regions and the occurrence of "salting out" at high guest salt concentrations [6]. These are some of the most important disadvantages of the classical POE/salt electrolytes that have severely hindered their practical application in solid-state electrochemical devices.

The sol-gel method is a versatile chemical synthetic route that permits the production, under mild reaction conditions, of ormolytes (organically modified silicate electrolytes). Relevant properties of novel electrolytes which may be "tailored" include specific density, thermal stability and mechanical properties. Ormolytes based on these materials are readily shaped into thin films and have an essentially amorphous character. Owing to their potential application in primary and secondary advanced batteries, the $\mathrm{Li}^{+}$-doped $\mathrm{POE} /$ siloxane ormolytes have been very extensively investigated [7-16]. Alkaline [17-18], alkaline-earth [19-21] and lanthanide [22-26] metal ions have also been introduced into this class of sol-gel derived host matrices.

In spite of its low electrode potential $(-0.76 \mathrm{~V}$ versus $\mathrm{NHE})$, zinc is considered to be a good candidate for the fabrication of rechargeable solid-state batteries. This element is abundant in nature, non-toxic, very stable and can be handled safely in oxygen and humid atmospheres and thus hazards in open air are minimized. Zinc-based devices have also relatively high specific and volumetric energy densities. Over the last few years, the technology of rechargeable alkaline manganese oxide/zinc batteries has progressed rapidly $[27,28]$. The number of reports referring to electrolytes formed with POE and zinc salts is, 
however, relatively low [29-33]. Although zinc perchlorate has been incorporated into POE [29], the most widely studied POE-based systems include those formed by the dissolution of halogen zinc salts $\left(\mathrm{ZnX}_{2}\right.$, where $\left.\mathrm{X}=\mathrm{Cl}[30-32], \mathrm{Br}[31,32], \mathrm{I}[30,31]\right)$ in the polymer host. Gel polymer electrolytes (GPEs) composed of poly(vinylidenefluoride) (PVDF) [34] or poly(methylmethacrylate) (PMMA) [35], plasticized with propylene carbonate and ethylene carbonate and doped with $\mathrm{Zn}\left(\mathrm{CF}_{3} \mathrm{SO}_{3}\right)_{2}$ have also been characterized.

In the present study we have examined a new family of sol-gel derived di-urea crosslinked POE/siloxane ormolytes (designated as di-ureasils [36,37]) incorporating $\mathrm{Zn}\left(\mathrm{CF}_{3} \mathrm{SO}_{3}\right)_{2}$. To the best of our knowledge this is the first time that $\mathrm{Zn}^{2+}$-doped hybrid electrolytes have been synthesized and their structure, morphology, thermal properties and ionic conductivity have been reported. In the di-ureasil host matrix employed, designated as d-U(2000) (where d stands for di, U denotes the urea group and 2000 is the average molecular weight of the starting organic precursor, which corresponds to about 40.5 oxyethylene repeat units), the extraordinary ability of the POE segments to dissolve guest salt species is combined with the chemical, mechanical and thermal stability of the siliceous network. In addition, the d$\mathrm{U}(2000)$ framework is only slightly hygroscopic and remains amorphous even at extremely high salt contents $[16,20]$. Since Berthier et al. [38] demonstrated that ion conduction occurred exclusively in the amorphous regions of electrolytes, research in this domain has been directed almost exclusively towards SPE systems devoid of crystalline domains. Although very recent data obtained by Gadjourova et al. [39] suggest that ionic conductivity in the crystalline fraction of the polymer phase can be significantly higher than in the amorphous regions, most of the research currently performed in this field continues to be directed toward the characterization of entirely amorphous materials. 


\section{Experimental}

\subsection{Synthesis}

$\mathrm{Zn}\left(\mathrm{CF}_{3} \mathrm{SO}_{3}\right)_{2}$ (Aldrich) and $\mathrm{O}, \mathrm{O}^{\prime}$-Bis(2-aminopropyl) polypropylene glycol-blockpolyethylene glycol-block-polypropylene glycol (commercially designated as Jeffamine ED$2001 \AA$, Fluka, average molecular weight $2001 \mathrm{~g} / \mathrm{mol}$ ) were dried under vacuum at $25^{\circ} \mathrm{C}$ for several days prior to being used. 3-isocyanatepropyltriethoxysilane (ICPTES, Fluka) was used as received. Ethanol $\left(\mathrm{CH}_{3} \mathrm{CH}_{2} \mathrm{OH}\right.$, Merck) and tetrahydrofuran (THF, Merck) were stored over molecular sieves. High purity distilled water was used in all experiments.

The $\mathrm{Zn}\left(\mathrm{CF}_{3} \mathrm{SO}_{3}\right)_{2}$-based di-ureasils were prepared according to the method described in detail elsewhere for the $\mathrm{Li}^{+}$- based analogues [16]. In agreement with the terminology adopted previously $[16,20,21,23]$, the xerogels have been identified by the notation d$\mathrm{U}(2000)_{\mathrm{n}} \mathrm{Zn}\left(\mathrm{CF}_{3} \mathrm{SO}_{3}\right)_{2}$. The $\mathrm{Zn}\left(\mathrm{CF}_{3} \mathrm{SO}_{3}\right)_{2}$ content of samples and other relevant information are collected in Table 1.

\subsection{Characterization}

${ }^{29} \mathrm{Si}$ magic-angle spinning (MAS) and ${ }^{13} \mathrm{C}$ cross-polarization (CP) MAS NMR spectra were recorded on a Bruker Avance $400(9.4 \mathrm{~T})$ spectrometer at 79.49 and $100.62 \mathrm{MHz}$, respectively. ${ }^{29}$ Si MAS NMR spectra were recorded with $2 \mu \mathrm{s}\left(\theta \approx 30^{\circ}\right)$ rf pulses, and recycle delay of $60 \mathrm{~s}$ and at a $5.0 \mathrm{kHz}$ spinning rate. ${ }^{13} \mathrm{C} \mathrm{CP} / \mathrm{MAS}$ NMR spectra were recorded with 4 $\mu \mathrm{s}{ }^{1} \mathrm{H} 90^{\circ}$ pulse, $2 \mathrm{~ms}$ contact time, a recycle delay of $4 \mathrm{~s}$ and at a spinning rate of $8 \mathrm{kHz}$. Chemical shifts $(\delta)$ are quoted in ppm from tetramethylsilane (TMS). To analyse quantitatively the peaks observed in the ${ }^{29} \mathrm{Si}$ MAS NMR spectra, the iterative least-squares curve-fitting procedure in the PeakFit software (Jandel Corporation, 2591 Rerner Boulevard, San Rafael, CA 94901, USA) was used. The best fit of the experimental data was sought by varying the frequency, bandwidth and intensity of the peaks and by employing Voigt band 
shapes (a mixture of Lorentzian and Gaussian contributions). The standard errors of the curve-fitting procedure were less than 0.01 .

Differential Scanning Calorimetric (DSC) measurements were obtained in a DSC131 Setaram DSC. Disk sections with masses of approximately $20 \mathrm{mg}$ were removed from the ormolyte, placed in $40 \mu \mathrm{l}$ aluminium cans and stored in a dessicator over phosphorous pentoxide $\left(\mathrm{P}_{2} \mathrm{O}_{5}\right)$ for one week at room temperature under vacuum. After this drying treatment the cans were hermetically sealed and the thermograms were recorded. Each sample was heated from 25 to $300{ }^{\circ} \mathrm{C}$ at $10 \mathrm{C} \mathrm{min}^{-1}$. The purge gas used in all experiments was high purity nitrogen $\left(\mathrm{N}_{2}\right)$ supplied at a constant $35 \mathrm{~cm}^{3} \mathrm{~min}^{-1}$ flow rate.

The X-ray diffraction (XRD) patterns were recorded at room temperature with a Rigaku Geigerflex D/max-c diffractometer system using monochromated $\mathrm{CuK}_{\alpha}$ radiation $(\lambda=1.541$ $\AA$ ) over the $2 \theta$ range of between 10 and $80^{\circ}$ and at a resolution of $0.05^{\circ}$. The samples were analyzed as powders and were not submitted to any thermal pre-treatment.

Samples for thermogravimetric studies (materials with $\mathrm{n}=200,60,40,20,10,5$ and 1) were transferred to open platinum crucibles and analyzed using a Rheometric Scientific TG 1000 thermobalance at a heating rate of $10^{\circ} \mathrm{C} \mathrm{min}^{-1}$ using dry $\mathrm{N}_{2}$ as purging gas $\left(20 \mathrm{~cm}^{3} \mathrm{~min}^{-1}\right)$. Prior to measurement, the xerogels were vacuum-dried at $80{ }^{\circ} \mathrm{C}$ for about $48 \mathrm{~h}$ and stored in an argon-filled glove box.

The total ionic conductivity of materials was determined by locating an ormolyte disk between two $10 \mathrm{~mm}$ diameter ion-blocking gold electrodes (Goodfellow, $>99.9 \%$ ). Prior to characterization, the di-ureasil ormolytes were vacuum-dried at $80^{\circ} \mathrm{C}$ for about $48 \mathrm{~h}$ and stored in an argon-filled glove box. The electrode/ormolyte/electrode assembly was secured in a suitable constant-volume support [40] which was installed in a Buchi TO 51 tube oven. A calibrated type $\mathrm{K}$ thermocouple, placed close to the ormolyte disk, was used to measure the sample temperature with a precision of about $0.2{ }^{\circ} \mathrm{C}$ and samples were characterized over a temperature range of between 25 and $100{ }^{\circ} \mathrm{C}$. Bulk conductivities of the samples were 
obtained during heating cycles using the complex plane impedance technique (Schlumberger Solartron 1250 frequency response analyser and 1286 electrochemical interface) over a frequency range of $65 \mathrm{kHz}$ to $0.5 \mathrm{~Hz}$. The electrolyte behaviour was found to be almost ideal and bulk conductivities were extracted in the conventional manner from impedance data. Reproducibility of measurements was better than $5 \%$.

\section{Results and Discussion}

\subsection{Structure and Morphology}

The ${ }^{29} \mathrm{Si}$ MAS NMR spectra of $\mathrm{Zn}^{2+}$-based di-ureasils with $\mathrm{n}=200$ and 10 exhibit three signals at $-52,-58$ and $-66 \mathrm{ppm}$ (Fig. 1). On the basis of the conventional $\mathrm{T}^{\mathrm{m}}$ silicon (Si) notation (where $\mathrm{m}^{*}=1,2$ and 3 represents the number of $\mathrm{Si}$ atoms bonded to O-Si units) these resonances are ascribed to $T^{1}, T^{2}$ and $T^{3}$ sites, respectively (Table 2). The relative population of the three Si environments demonstrates that in both samples the dominating environment is $\mathrm{T}^{3}$ (Table 2), meaning that under the experimental conditions applied the condensation reactions favoured the growth of branched structures. The degrees of polycondensation c reported in Table 2 are significantly higher than those observed in the non-doped framework (75\%) [41]. On the basis of the empirical formula deduced for the two xerogels (Table 2), which suggest that a few terminal $\mathrm{OCH}_{2} \mathrm{CH}_{3}$ or $\mathrm{OH}$ groups persist bonded to the Si atoms, we propose that these composites have the idealized structure (Scheme 1).

The diffractograms of the $\mathrm{Zn}\left(\mathrm{CF}_{3} \mathrm{SO}_{3}\right)_{2}$-based di-ureasils with $200 \geq \mathrm{n} \geq 5$ illustrated in Fig. 2 lead us to conclude that these samples are entirely amorphous. The characteristic amorphous broad peak, Gaussian in shape and centered at approximately $21.61^{\circ}$ in these patterns, is attributed to the coherent diffracting regions of the siliceous network [42]. The second-order

\footnotetext{
* The conventional notation $\mathrm{T}^{\mathrm{n}}$ has been changed to $\mathrm{T}^{\mathrm{m}}$, to avoid any confusion with the notation $\mathrm{n}$ used for salt composition throughout the text.
} 
of this peak is observed as a broad, low-intensity hump located around $40^{\circ}$ in the XRD patterns of the samples with $20 \geq \mathrm{n} \geq 10$ (Fig. 2). A structural unit distance of 4.2 and $4.3 \AA$ was obtained for the hybrids with $200 \geq n \geq 10$ and $n \leq 7$, respectively, using the Bragg law. The coherent length $\mathrm{L}$ over which the structural unit survives in the $\mathrm{Zn}^{2+}$-doped di-ureasils was estimated using the modified Scherrer equation $L=I \lambda /(A \cos \theta)$, where $A$, in radians, is the integrated area of the peaks and I their intensity. Coherent lengths of 11 and $13 \AA$ were derived for hybrids with $200 \geq n \geq 20$ and $n \leq 10$, respectively. These values of $L$ are similar to those reported for the non-doped di-ureasils [43]. In the XRD pattern of the hybrid with $n=$ 1, a series of intense and sharp Bragg reflections are evident (Fig. 2). As these peaks do not coincide with those of the pure salt, they have been attributed to a crystalline $\mathrm{POE} / \mathrm{Zn}\left(\mathrm{CF}_{3} \mathrm{SO}_{3}\right)_{2}$ complex of unknown stoichiometry [6].

\subsection{Thermal properties}

The DSC curves of the d-U(2000) $\mathrm{Zn}_{\mathrm{n}}\left(\mathrm{CF}_{3} \mathrm{SO}_{3}\right)_{2}$ ormolytes with $200>\mathrm{n}>5$ (Fig. 3) demonstrate that these materials are amorphous, a result that corroborates the XRD data. The weak, broad endotherms centered around $150^{\circ} \mathrm{C}$ (with onset temperatures of about $75^{\circ} \mathrm{C}$ ) seen in the thermograms of the concentrated samples with $n=7$ and 5 (Fig. 3) are ascribed to the evaporation of occluded solvents (water, ethanol or THF). As the d-U(2000) matrix is only slightly hygroscopic, the presence of minor traces of water must be associated with the zinc salt. Water from the salt-containing xerogels could be readily removed by drying the samples under vacuum at room temperature in the presence of a $\mathrm{P}_{2} \mathrm{O}_{5}$. The efficiency of the drying procedure was monitored by means of infrared spectroscopy. The profile of the $\mathrm{OH}$ stretching envelope in the high-frequency region of the FT-IR spectra of the d-U(2000) ${ }_{n} \mathrm{Zn}\left(\mathrm{CF}_{3} \mathrm{SO}_{3}\right)_{2}$ composites confirms that the amount of residual water in the samples is negligible (see Fig. 1 of Ref. 44). The origin of the set of endotherms centred around $84,106,160$ and $177^{\circ} \mathrm{C}$ in the DSC curve of the salt-rich xerogel with $n=1$ (Fig. 3) is not clear. 
The TGA curves of representative $\mathrm{Zn}\left(\mathrm{CF}_{3} \mathrm{SO}_{3}\right)_{2}$-doped ormolytes with $200 \geq \mathrm{n} \geq 20$ and $\mathrm{n} \leq 10$ are reproduced in Figs.4(a) and 4(b), respectively. The d-U(2000) $\mathrm{Zn}\left(\mathrm{CF}_{3} \mathrm{SO}_{3}\right)_{2}$ diureasils with $n \geq 20$ are thermally stable up to about $300^{\circ} \mathrm{C}$ (Fig. $4(\mathrm{a})$ ), a value very close to that reported for the non-doped matrix [16]. At about $420{ }^{\circ} \mathrm{C}$ a mass loss was observed that decreased with increasing salt concentration (Fig. 4(a)). In the case of the di-ureasils with $n=$ 40 and 20 a slight mass loss was observed at around $32{ }^{\circ} \mathrm{C}$, probably due to solvent and water loss. Thermal degradation in the samples with $\mathrm{n}=10$ and 5 takes places in three stages: a slight gradual mass loss takes place around $50{ }^{\circ} \mathrm{C}$, followed by two abrupt changes, one at 280 and the other at $410{ }^{\circ} \mathrm{C}$ (Fig. 4(b)). In contrast, the most concentrated compound analyzed (n= 1) suffers a marked weight loss at only $32{ }^{\circ} \mathrm{C}$, followed by a further event at about $300{ }^{\circ} \mathrm{C}$ and by an abrupt decomposition that is initiated at $500{ }^{\circ} \mathrm{C}$ (Fig. 4(b)). The major degradation of this d-U(2000) ${ }_{1} \mathrm{Zn}\left(\mathrm{CF}_{3} \mathrm{SO}_{3}\right)_{2}$ di-ureasil sample occurs in the latter stage (Fig. 4(b)). These data allow us to assign the endotherms evident in the DSC thermograms of the salt-rich diureasil $(n=1)$ to the coupled effect of fusion of the crystalline $\mathrm{POE} / \mathrm{Zn}\left(\mathrm{CF}_{3} \mathrm{SO}_{3}\right)_{2}$ complex identified by XRD (Fig. 2) and degradation reactions.

\subsection{Ionic conductivity}

The Arrhenius conductivity plots and the graph of the conductivity isotherms of the d$\mathrm{U}(2000)_{\mathrm{n}} \mathrm{Zn}\left(\mathrm{CF}_{3} \mathrm{SO}_{3}\right)_{2}$ ormolytes with $\infty>\mathrm{n} \geq 1$ are depicted in Figs. 5 and 6 , respectively. The $\mathrm{Zn}^{2+}$-doped di-ureasils with $\mathrm{n} \geq 20$ display moderate levels of ionic conductivity over the whole range of temperatures considered (Fig. 5(a)). At 30 and $100{ }^{\circ} \mathrm{C}$ the ormolytes with the highest conductivity are $\mathrm{d}-\mathrm{U}(2000)_{60} \mathrm{Zn}\left(\mathrm{CF}_{3} \mathrm{SO}_{3}\right)_{2} \quad\left(2.7 \times 10^{-6} \quad \mathrm{~S} \quad \mathrm{~cm}^{-1}\right)$ and $\mathrm{d}-$ $\mathrm{U}(2000)_{20} \mathrm{Zn}\left(\mathrm{CF}_{3} \mathrm{SO}_{3}\right)_{2}\left(7 \times 10^{-5} \mathrm{~S} \mathrm{~cm}^{-1}\right)$, respectively (Figs. 5(a) and 6). At higher salt concentration $(\mathrm{n} \leq 10)$ the ionic conductivity suffers a marked decrease ((Figs. 5(b) and 6). The surprisingly low ionic conductivity exhibited by the salt-rich hybrid with $n=1$ (below 60 ${ }^{\circ} \mathrm{C}$ it is even lower than that of the non-doped hybrid (Fig. 5(b)), which was attributed to 
proton hopping between the urea groups [36,37]) correlates well with the existence of a crystalline $\mathrm{POE} / \mathrm{Zn}\left(\mathrm{CF}_{3} \mathrm{SO}_{3}\right)_{2}$ complex, which globally reduces the proportion of amorphous material in the sample and consequently restricts polymer segment mobility and ion transport $[6]$.

At ambient temperature electrolytes produced by the sol-gel process show an improvement over the poor conductivity typically exhibited by POE-based electrolytes. This is a consequence of the high proportion of crystalline material present in the latter material. In the $\mathrm{Zn}\left(\mathrm{CF}_{3} \mathrm{SO}_{3}\right)_{2}$-based di-ureasil compounds with $100 \geq \mathrm{n} \geq 10$ the ionic conductivity varies from $10^{-6}$ to $10^{-5} \mathrm{~S} \mathrm{~cm}^{-1}$ at room temperature, whereas the conventional PEO-based solid electrolytes yield conductivities of the order of $10^{-8} \mathrm{~S} \mathrm{~cm}^{-1}$ [45].

The ionic conductivity displayed by the $\mathrm{d}-\mathrm{U}(2000)_{\mathrm{n}} \mathrm{Zn}\left(\mathrm{CF}_{3} \mathrm{SO}_{3}\right)_{2}$ xerogels is significantly lower than the conductivity maxima exhibited by the $\mathrm{Zn}\left(\mathrm{CF}_{3} \mathrm{SO}_{3}\right)_{2}$-doped SPE reported by Ikeda et al [33] $\left(2.1 \times 10^{-4} \mathrm{~S} \mathrm{~cm}^{-1}\right.$ at room temperature for a sample containing $4 \mathrm{~mol} \%$ $\left.\mathrm{Zn}\left(\mathrm{CF}_{3} \mathrm{SO}_{3}\right)_{2}\right)$ and by the PVDF- and PMMA-based GPEs of Kumar et al. $\left(3.94 \times 10^{-3} \mathrm{~S} \mathrm{~cm}^{-1}\right.$ at $25^{\circ} \mathrm{C}$ [34] and $1.3 \times 10^{-3} \mathrm{~S} \mathrm{~cm}^{-1}$ at $27^{\circ} \mathrm{C}$ [35], respectively). GPEs are however expected to have a greater propensity for interfacial problems than ormolytes [46]. Thus, in this sense, sol-gel derived materials such as the ones proposed here may be a viable alternative.

\section{Conclusions}

Novel $\mathrm{Zn}\left(\mathrm{CF}_{3} \mathrm{SO}_{3}\right)_{2}$-doped di-ureasil ormolytes with $\infty>\mathrm{n} \geq 1$ were synthesized by the sol-gel process. Materials with $\mathrm{n} \geq 5$ were obtained as completely amorphous, transparent and flexible thin monolithic films. In the compound with $n=1$, produced as a white powder, a crystalline $\mathrm{POE} / \mathrm{Zn}\left(\mathrm{CF}_{3} \mathrm{SO}_{3}\right)_{2}$ complex of unknown stoichiometry is formed. The xerogels with $200>\mathrm{n} \geq 20$ are thermally stable up to $305^{\circ} \mathrm{C}$. At 30 and $100{ }^{\circ} \mathrm{C}$, the most conducting di-ureasils are d-U(2000) ${ }_{60} \mathrm{Zn}\left(\mathrm{CF}_{3} \mathrm{SO}_{3}\right)_{2}\left(3 \times 10^{-6} \mathrm{~S} \mathrm{~cm}^{-1}\right)$ and d-U(2000) ${ }_{20} \mathrm{Zn}\left(\mathrm{CF}_{3} \mathrm{SO}_{3}\right)_{2}\left(7 \times 10^{-5}\right.$ $\left.\mathrm{S} \mathrm{cm}^{-1}\right)$, respectively. 
The encouraging results obtained in the present work suggest that further studies on the zinc-doped d-U(2000)-based di-ureasil ormolytes are worth pursuing. In particular, the replacement of the triflate ion by a more suitable anion is expected to result in a significant increase of the ionic conductivity values.

\section{Acknowledgements}

Financial support from the Fundação para a Ciência e Tecnologia (POCTI/P/CTM/46780/03 and SFRH/BD/13559/03) is gratefully acknowledged.

\section{References}

[1] P. Gomez-Romero, C. Sanchez (Eds), Functional Hybrid Materials, Wiley Interscience, New York, 2003

[2] C. J. Brinker, G. W. Scherer, Sol-Gel Science: The Physics and Chemistry of Sol-Gel Processing, Academic Press, San Diego, CA, 1990.

[3] J. D. Mackenzie, J. Sol-Gel Sci. \& Technol. 26 (2003) 23.

[4] S. Sakka, J. Sol-Gel Sci. \& Technol. 26 (2003) 29.

[5] U. Schubert, J. Sol-Gel Sci. \& Technol. 26 (2003) 47.

[6] F. M. Gray, Polymer Electrolytes, RSC Materials Monographs, The Royal Society of Chemistry, London, 1997.

[7] D. Ravaine, A. Seminel, Y. Charbouillot, M. Vincens, J. Non-Cryst. Solids 82 (1986) 210

[8] M. Popall, M. Andrei, J. Kappel, J. Kron, K. Olma, B. Olsowski, Electrochim. Acta, 43 (10-11) (1998) 1155.

[9] P. Judeinstein, J. Titman, M. Stamm, H. Schmidt, Chem. Mater. 6 (1994) 127.

[10] K. Dahmouche, M. Atik, N. C. Mello, T. J. Bonagamba, H. Panepucci, M. A. Aegerter, P. Judeinstein, J. Sol-Gel Sci. Technol. 8 (1997) 711. 
[11] V. de Zea Bermudez, L. Alcácer, J. L. Acosta, E. Morales, Solid State Ionics 116 (1999) 197

[12] C. Wang, Y. Wei, G. R. Ferment, W. Li, T. Li, Mater. Lett. 39 (1999) 206

[13] J. R. MacCallum, S. Seth, Eur. Polym. J. 36 (2000) 2337

[14] K. Nishio, T. Tsuchiya, Sol. Energy Mater. Sol. Cells 68 (2001) 295

[15] S. M. Gomes, V. de Zea Bermudez, M. M. Silva, S. Barros, R. A. Sá Ferreira, L. D. Carlos, A. P. Passos de Almeida, M. J. Smith, Electrochim. Acta 47(15) (2002) 2421.

[16] S. C. Nunes, V. de Zea Bermudez, M. M. Silva, S. Barros, M. J. Smith, L. D. Carlos, J. Rocha, E. Morales, J. Electrochem. Soc. 152(2) (2005) A429.

[17] V. de Zea Bermudez, S. M. Gomes Correia, M. M. Silva, S. Barros, M. J. Smith, R. A. Sá Ferreira, L. D. Carlos, C. Molina, K. Dahmouche, S. J. L. Ribeiro, J. Sol-Gel. Sci. Tech. $26(2003) 1$

[18] S. M. Gomes Correia, V. de Zea Bermudez, M. M. Silva, S. Barros, R. A. Sá Ferreira, L. D. Carlos, A. P. Passos de Almeida, M. J. Smith, Solid State Ionics 156(1-2) (2003) 85

[19] S. Mitra, S. Sampath, J. Mater. Chem. 12 (2002) 2531

[20] S. C. Nunes, V. de Zea Bermudez, M. M. Silva, S. Barros, M. J. Smith, E. Morales, L. D. Carlos, J. Rocha, Solid State Ionics, 176 (2005) 1591.

[21] S. C. Nunes, V. de Zea Bermudez, D. Ostrovskii, L. D. Carlos, Solid State Ionics, 176 (2005), 1601.

[22] S. M. Gomes Correia, V. de Zea Bermudez, , R. A. Sá Ferreira, L. D. Carlos, M. M. Silva, S. Barros, M. J. Smith, Ionics 8(1-2) (2002) 73.

[23] S. C. Nunes, V. de Zea Bermudez, R. A. Sá Ferreira, L. D. Carlos, E. Morales, P.V.S. Marques, Mater. Res. Soc. Symp. Proc., Vol. 847, EE.13.31.1

[24] S. M. Gomes Correia, V. de Zea Bermudez, M. M. Silva, S. Barros, R. A. Sá Ferreira, L. D. Carlos, M. J. Smith, Electrochim. Acta 47(15) (2002) 2551. 
[25] M. M. Silva, V. de Zea Bermudez, L. D. Carlos, A. P. Passos de Almeida, M. J. Smith, J. Mater. Chem.9 (1999) 1735.

[26] M. M. Silva, V. de Zea Bermudez, L. D. Carlos, M. J. Smith, Electrochim. Acta 45 (2000) 1467.

[27] F. R. McLarnon, E. J. Cairns, J. Electrochem. Soc. 138 (1991) 645

[28] J.-Y. Huot, in: O. Sovadogo, P. R. Roberge (Eds.), Advances in Zinc Battery, Proc. Second International Symposium on New Materials for Fuel Cells and Modern Battery System, 1997, p. 137

[29] A. Patrick, M. Glasse, R. Latham, R. Linford, Solid State Ionics 18/19 (1986) 1063

[30] T. M A. Abrantes, L. J. Alcácer, C. A. C. Sequeira, Solid State Ionics 18/19 (1986) 315

[31] G. C. Farrington, in: J. R. MacCallum, C. A. Vincent (Eds), Polymer Electrolyte Reviews 2, Elsevier Science Publishers, 1989, p. 255

[32] V. C. Z. Bermudez, J. Morgado, T. M. A. Abrantes, L. Alcácer, in: B. Scrosati. (Ed.), Second International Symposium on Polymer Electrolytes, Elsevier Applied Science: London, 1990, p. 251

[33] S. Ikeda, Y. Mori, Y. Furuhashi, H. Masuda, Solid State Ionics 121 (1999) 329.

[34] G. Girish Kumar, S. Sampath, Solid State Ionics 160 (2003) 289.

[35] G. Girish Kumar, S. Sampath, Solid State Ionics 176(7-8) (2005) 773.

[36] M. Armand, C. Poinsignon, J.-Y. Sanchez, V. de Zea Bermudez, U.S. Patent 5, 283, 310, 1993.

[37] V. de Zea Bermudez, C. Poinsignon, M. B. Armand, J. Mater. Chem. 7(9) (1997) 1677.

[38] C. Berthier, W. Gorecki, M. Minier, M. B. Armand, J. M. Chabagno, P. Rigaud, Solid State Ionics $11(1983) 91$

[39] Z. Gadjourova, Y. G. Andreev, D. P. Tunstall, P. G. Bruce, Nature, 412 (2001) 520 
[40] C. J. R. Silva, M. J. Smith, Electrochim. Acta 40 (1995) 2389.

[41] L. D. Carlos, R. A. Sá Ferreira, I. Orion, V. de Zea Bermudez, J. Rocha, J. Lumin. 87-89 (2000) 702

[42] L. D. Carlos, V. de Zea Bermudez, R. A. Sá Ferreira, L. Marques, M. Assunção, Chem. Mater. 11(3) (1999) 581

[43] L. Fu, R. A. Sá Ferreira, N. J. O. Silva, L. D. Carlos, V. de Zea Bermudez, J. Rocha, Chem. Mater. 16 (2004) 1507.

[44] S. C. Nunes, V. de Zea Bermudez, D. Ostrovskii, L. D. Carlos, Vib. Spectrosc., 40(2) (2006) 278

[45] J. R. MacCallum, C. A. Vincent (Eds.), Polymer Electrolyte Reviews-1, Elsevier, London, 1987

[46] Pag. 44 of Chapter 2 of Reference 6. 


\section{List of figure captions}

Fig. $1 .{ }^{29} \mathrm{Si}$ MAS NMR spectra of selected d-U(2000) ${ }_{n} \mathrm{Zn}\left(\mathrm{CF}_{3} \mathrm{SO}_{3}\right)_{2}$ di-ureasils (a) and curve-fitting results (b)

Fig. 2. XRD curves of selected d-U(2000) ${ }_{n} \mathrm{Zn}\left(\mathrm{CF}_{3} \mathrm{SO}_{3}\right)_{2}$ di-ureasils.

Fig. 3. DSC patterns of the d-U(2000) $\mathrm{Zn}\left(\mathrm{CF}_{3} \mathrm{SO}_{3}\right)_{2}$ di-ureasils.

Fig. 4. TGA curves of selected $\mathrm{d}-\mathrm{U}(2000)_{\mathrm{n}} \mathrm{Zn}\left(\mathrm{CF}_{3} \mathrm{SO}_{3}\right)_{2}$ di-ureasils: (a) $200 \geq \mathrm{n} \geq 20$; (b) $\mathrm{n}=10,5$ and 1

Fig. 5. Arrhenius conductivity plot of the d-U(2000) ${ }_{n} \mathrm{Zn}\left(\mathrm{CF}_{3} \mathrm{SO}_{3}\right)_{2}$ di-ureasils: (a) $200 \geq$ $\mathrm{n} \geq 20$; (b) $\mathrm{n}=\infty .10,7,5$ and 1

Fig. 6. Composition dependence of the ionic conductivity of the d$\mathrm{U}(2000)_{\mathrm{n}} \mathrm{Zn}\left(\mathrm{CF}_{3} \mathrm{SO}_{3}\right)_{2}$ di-ureasils.

\section{Tables}

Table 1 Details of the synthetic procedure of the d-U(2000) ${ }_{n} \mathrm{Zn}\left(\mathrm{CF}_{3} \mathrm{SO}_{3}\right)_{2}$ di-ureasils.

Table $2{ }^{29} \mathrm{Si}$ MAS/NMR data of selected d-U(2000) ${ }_{\mathrm{n}} \mathrm{Zn}\left(\mathrm{CF}_{3} \mathrm{SO}_{3}\right)_{2}$ di-ureasils.

\section{Scheme}

Scheme 1 - Structure of d-U(2000) ${ }_{n} \mathrm{Zn}\left(\mathrm{CF}_{3} \mathrm{SO}_{3}\right)_{2}$ di-ureasils. 


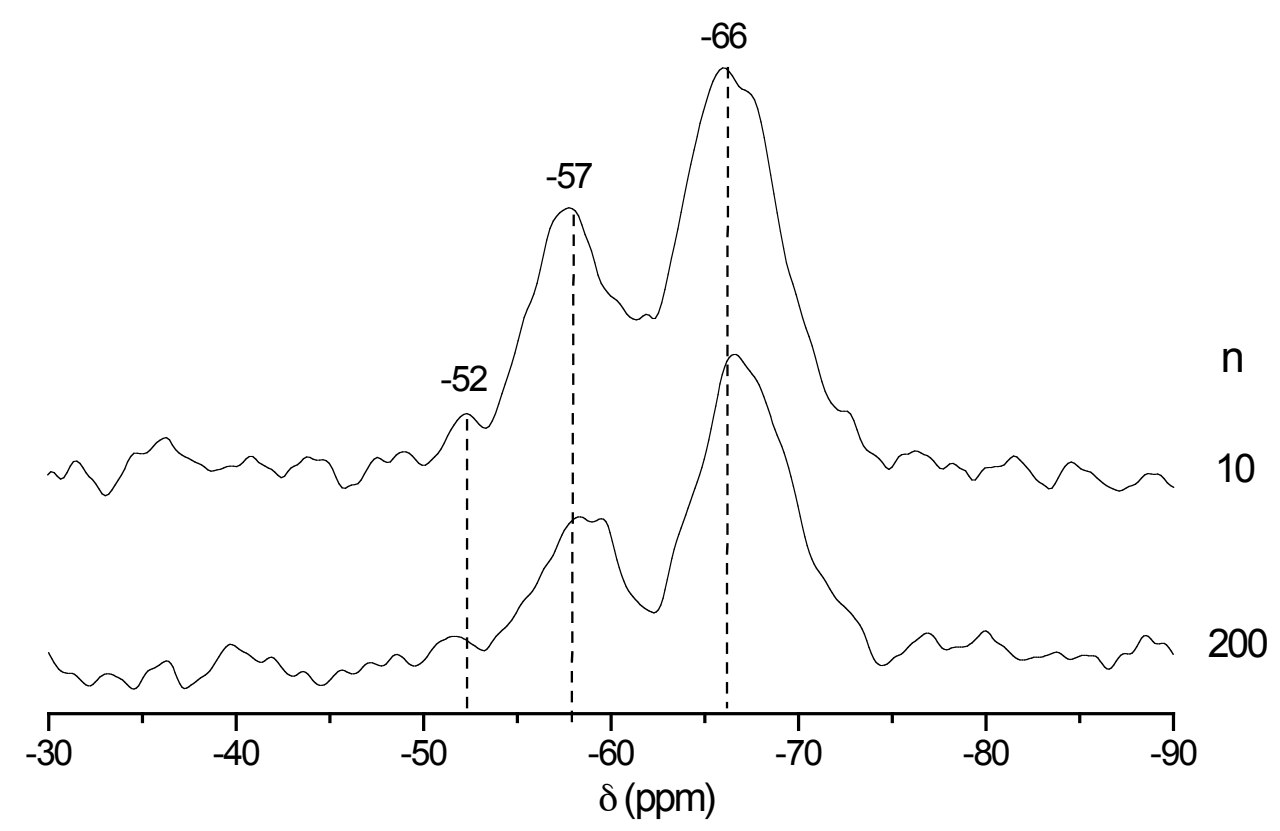

(a)

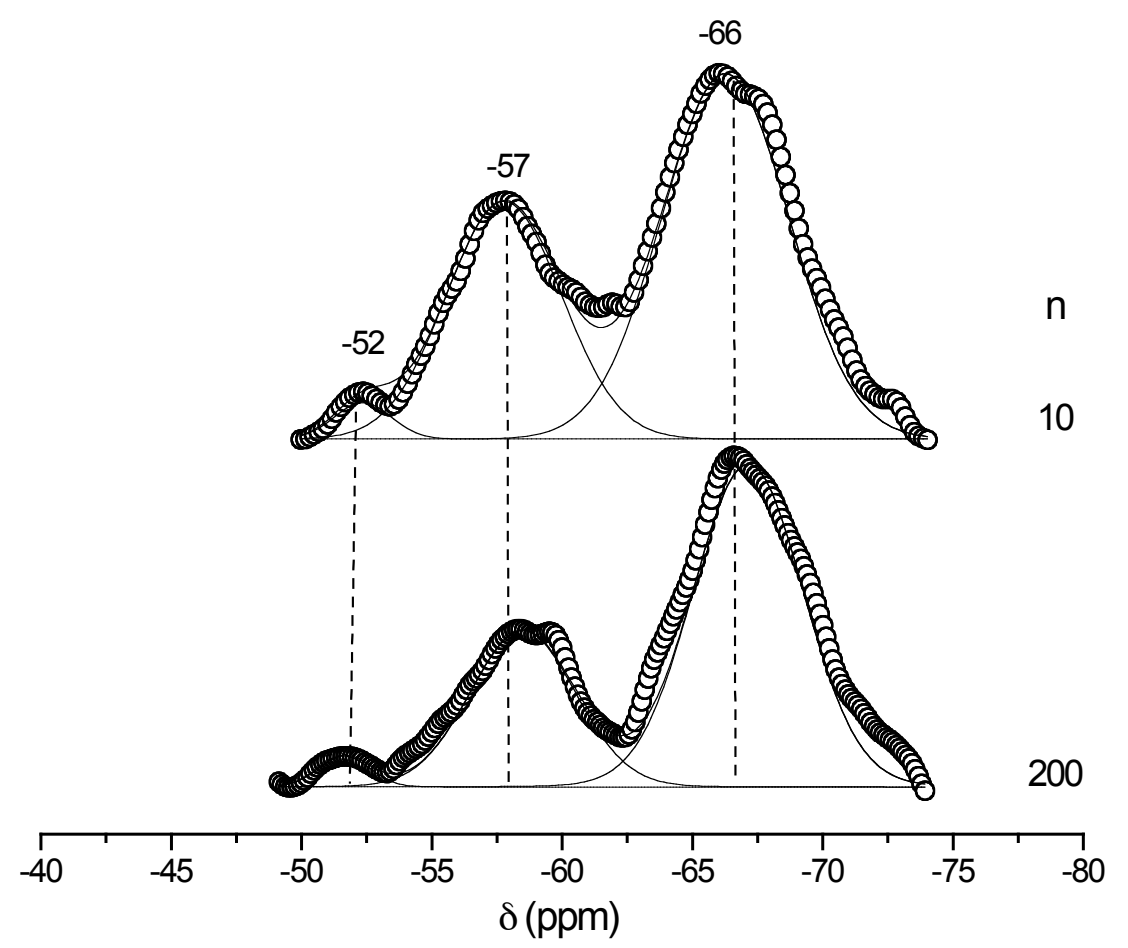

(b)

Fig. 1. S. C. Nunes et al., Solid State Sciences 


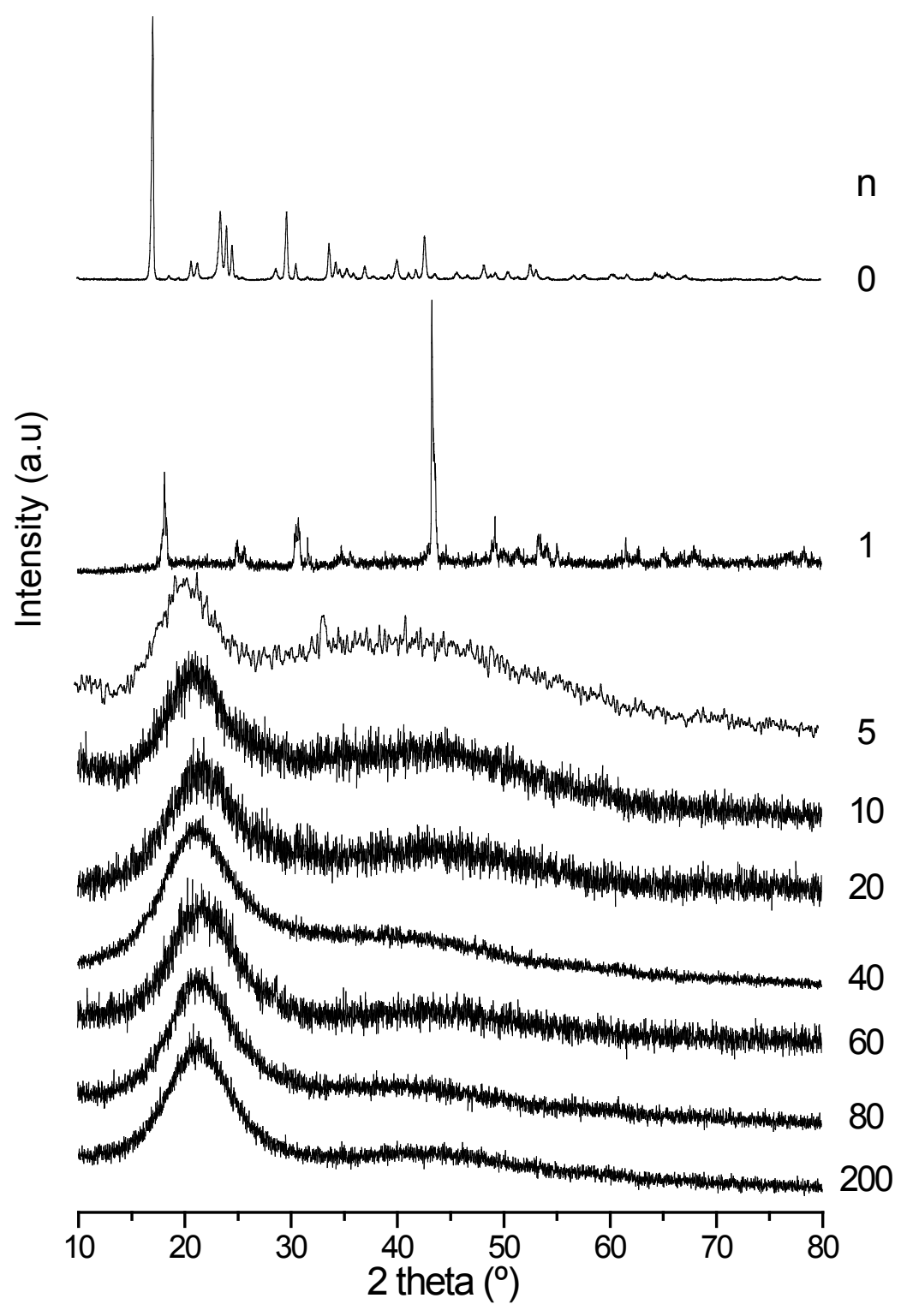

Fig. 2. S. C. Nunes et al., Solid State Sciences 


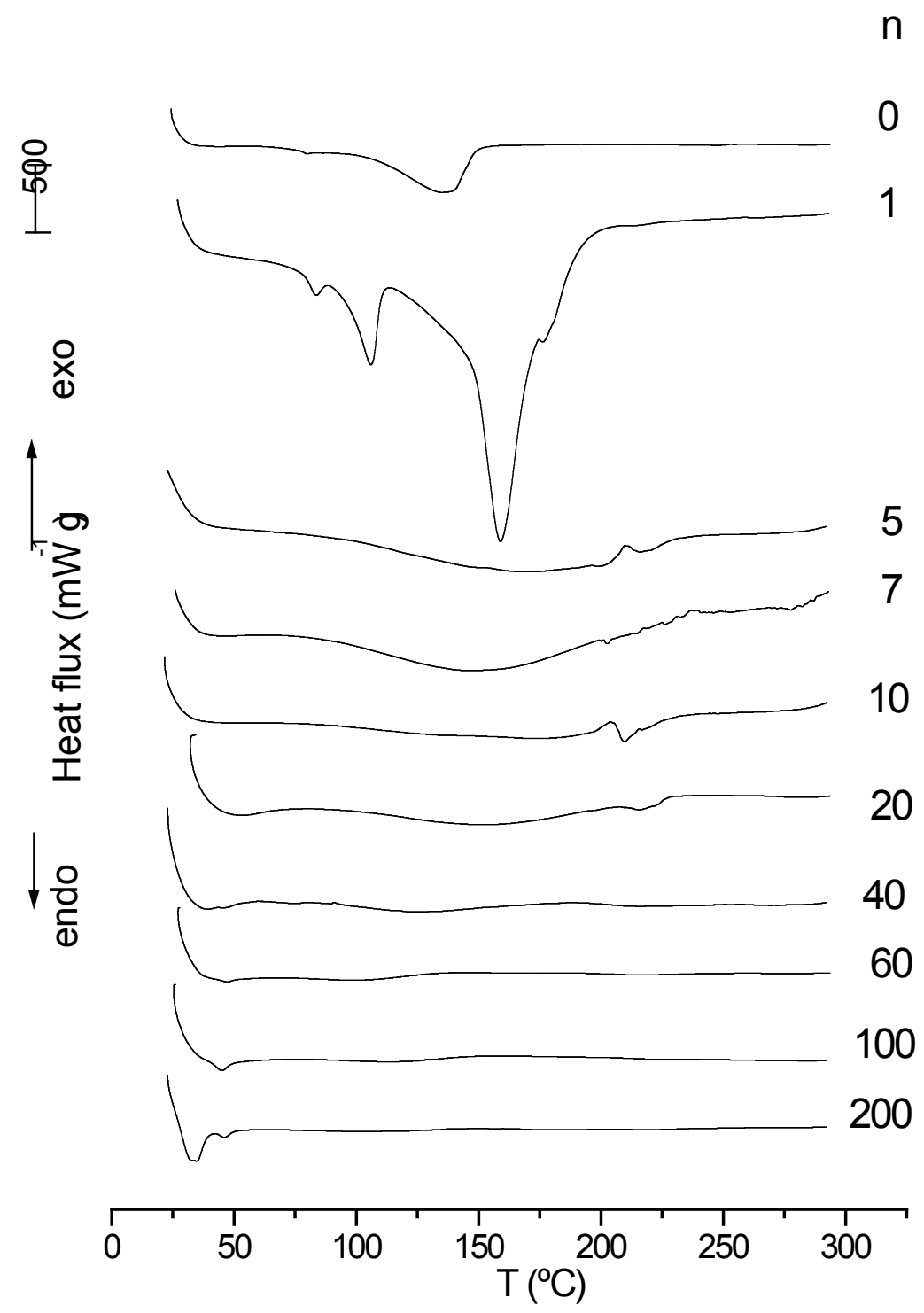

Fig. 3. S. C. Nunes et al., Solid State Sciences 


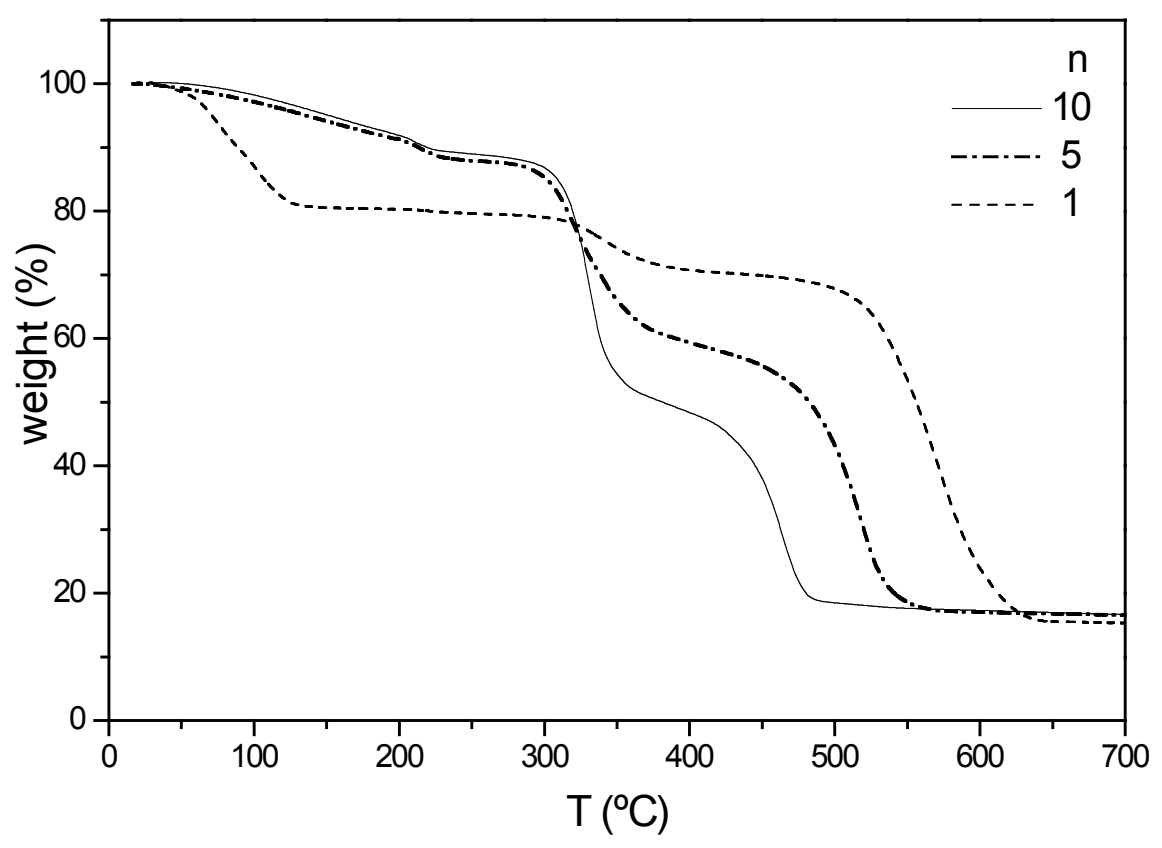

(a)

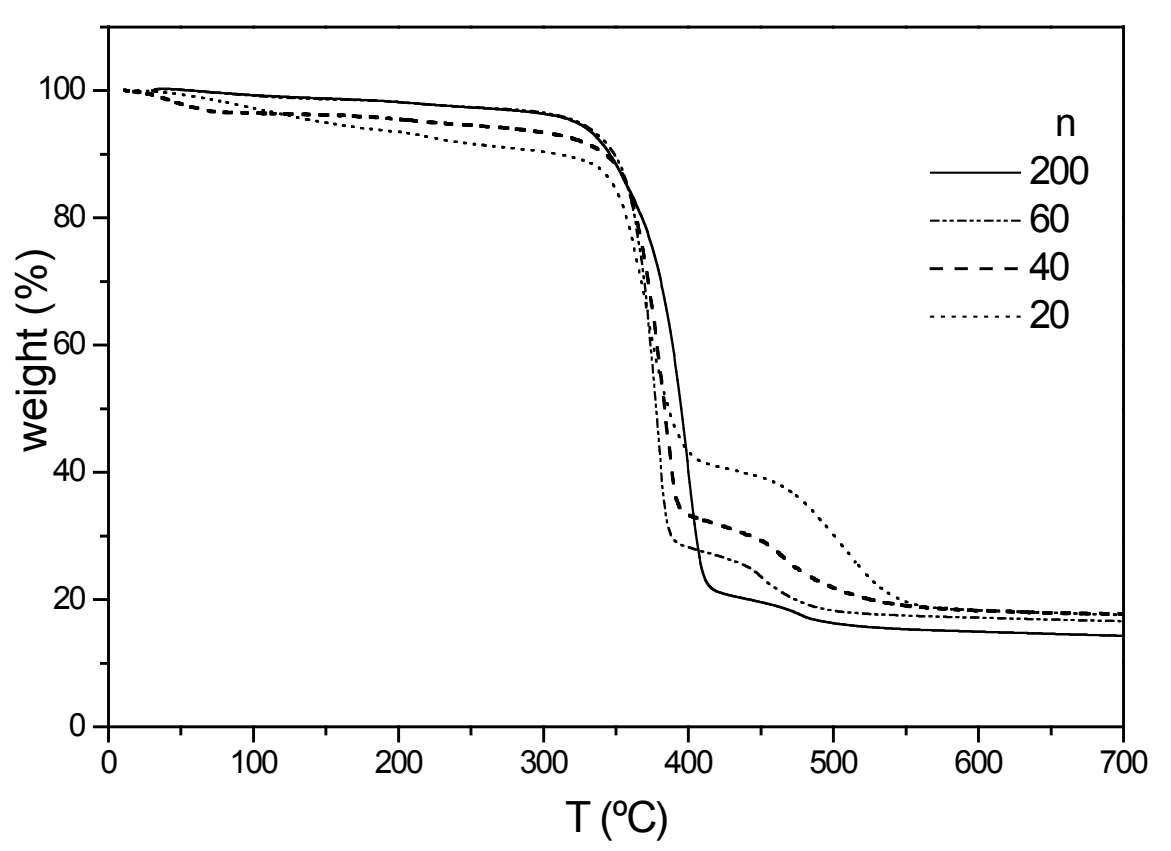

(b)

Fig. 4. S. C. Nunes et al., Solid State Sciences 
$\mathrm{T}\left({ }^{\circ} \mathrm{C}\right)$
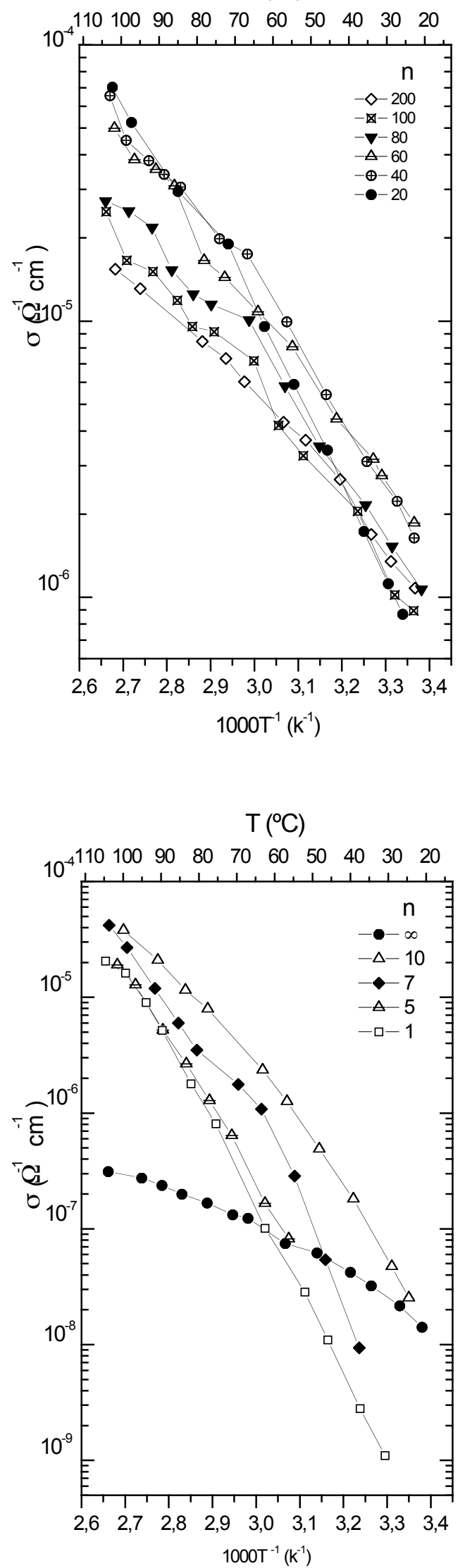

Figs. 5 a) and b). S. C. Nunes et al., Solid State Sciences 


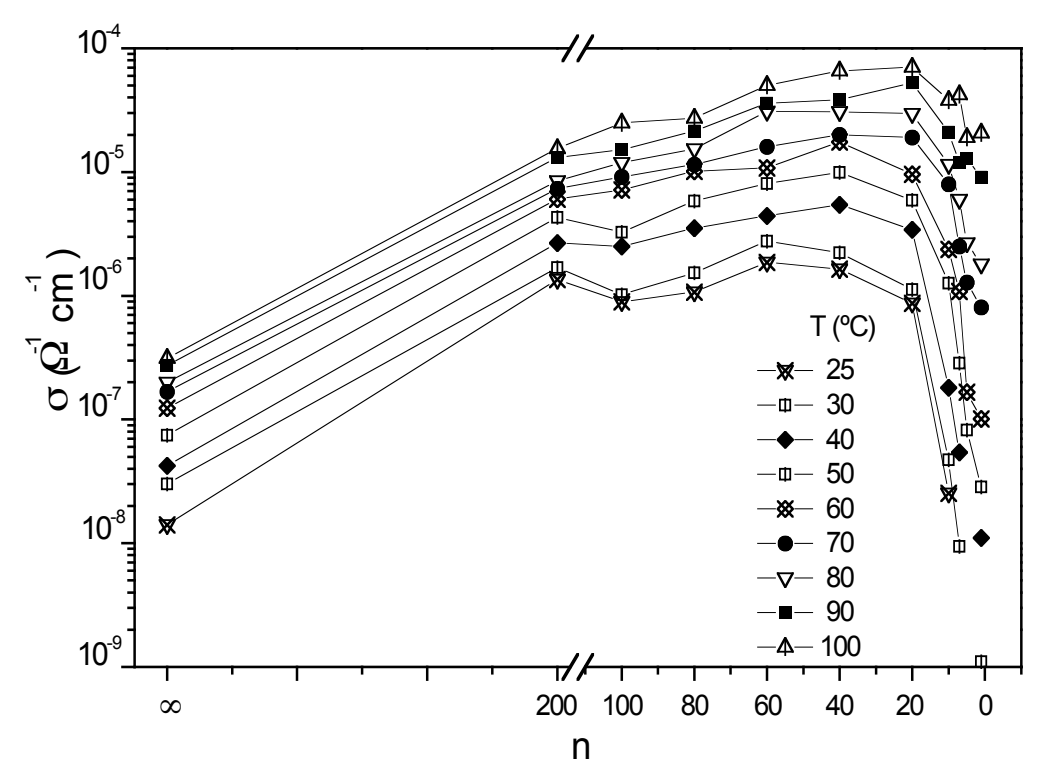

Fig. 6. S. C. Nunes et al., Solid State Sciences

Table 1. S. C. Nunes et al., Solid State Sciences

\begin{tabular}{|c|c|c|c|c|}
\hline $\begin{array}{l}\mathrm{n}=\mathrm{O} / \mathrm{Zn}^{2+} \\
\left(\mathrm{molmol}^{-1}\right)\end{array}$ & $\begin{array}{c}\mathrm{m}\left(\mathrm{Zn}\left(\mathrm{CF}_{3} \mathrm{SO}_{3}\right)_{2}\right) \\
(\mathrm{g})\end{array}$ & $\begin{array}{c}\mathrm{Si} / \mathrm{Zn}^{2+} \\
\left(\mathrm{molmol}^{-1}\right)\end{array}$ & $\begin{array}{r}\mathrm{Si} / \mathrm{Zn}^{2+} \\
\left(\mathrm{gg}^{-1}\right)\end{array}$ & $\begin{array}{c}\text { physical } \\
\text { appearance }\end{array}$ \\
\hline$\infty$ & - & - & - & $\begin{array}{l}\text { transparent film } \\
\text { yellowish hue }\end{array}$ \\
\hline 200 & 0.0920 & 9.8765 & 6.7206 & idem \\
\hline 100 & 0.1840 & 4.9383 & 3.3603 & idem \\
\hline 80 & 0.2300 & 3.9506 & 2.6883 & idem \\
\hline 60 & 0.3067 & 2.9630 & 2.0162 & idem \\
\hline 40 & 0.4601 & 1.9753 & 1.3441 & idem \\
\hline 20 & 0.9202 & 0.9876 & 0.6721 & idem \\
\hline 10 & 1.8404 & 0.4938 & 0.3360 & idem \\
\hline 7 & 2.6291 & 0.3457 & 0.2352 & idem \\
\hline 5 & 3.6807 & 0.2469 & 0.1680 & idem \\
\hline 1 & 18.4037 & 0.0494 & 0.0336 & white powder \\
\hline
\end{tabular}


Table 2. S. C. Nunes et al., Solid State Sciences

$$
\mathrm{T}^{\mathrm{m}} \text { (population in \%) }
$$

$\begin{array}{llllll}\mathrm{n} & \mathrm{T}^{1} & \mathrm{~T}^{2} & \mathrm{~T}^{3} & \mathrm{c}(\%) & \text { Empirical }\end{array}$

formula

\begin{tabular}{llllll}
\hline 200 & $-52(1)$ & $-58(27)$ & $-67(72)$ & 90 & $\mathrm{R}_{0.5}^{\prime} \mathrm{Si}$ \\
$(\mathrm{OR})_{0.30}(\mathrm{O})_{1.4}$ & & & \\
$10 \quad-52(1)$ & $-58(33)$ & $-66(66)$ & 88 & $\mathrm{R}^{\prime}{ }_{0.5} \mathrm{Si}$ \\
$(\mathrm{OR})_{0.36}(\mathrm{O})_{1.3}$ & & & &
\end{tabular}

Notes:

$c=1 / 3\left(\% T^{1}+2 \% T^{2}+3 \% T^{3}\right)$

$\mathrm{T}^{1}=\mathrm{CH}_{2} \mathrm{Si}(\mathrm{OSi})(\mathrm{OR})_{2} ; \mathrm{T}^{2}=\mathrm{CH}_{2} \mathrm{Si}(\mathrm{OSi})_{2}(\mathrm{OR}), \mathrm{T}^{3}=\mathrm{CH}_{2} \mathrm{Si}(\mathrm{OSi})_{3}$

$\mathrm{R}=\mathrm{H}$ or $\mathrm{CH}_{2} \mathrm{CH}_{3}$

Scheme 1. S. C. Nunes et al., Solid State Sciences
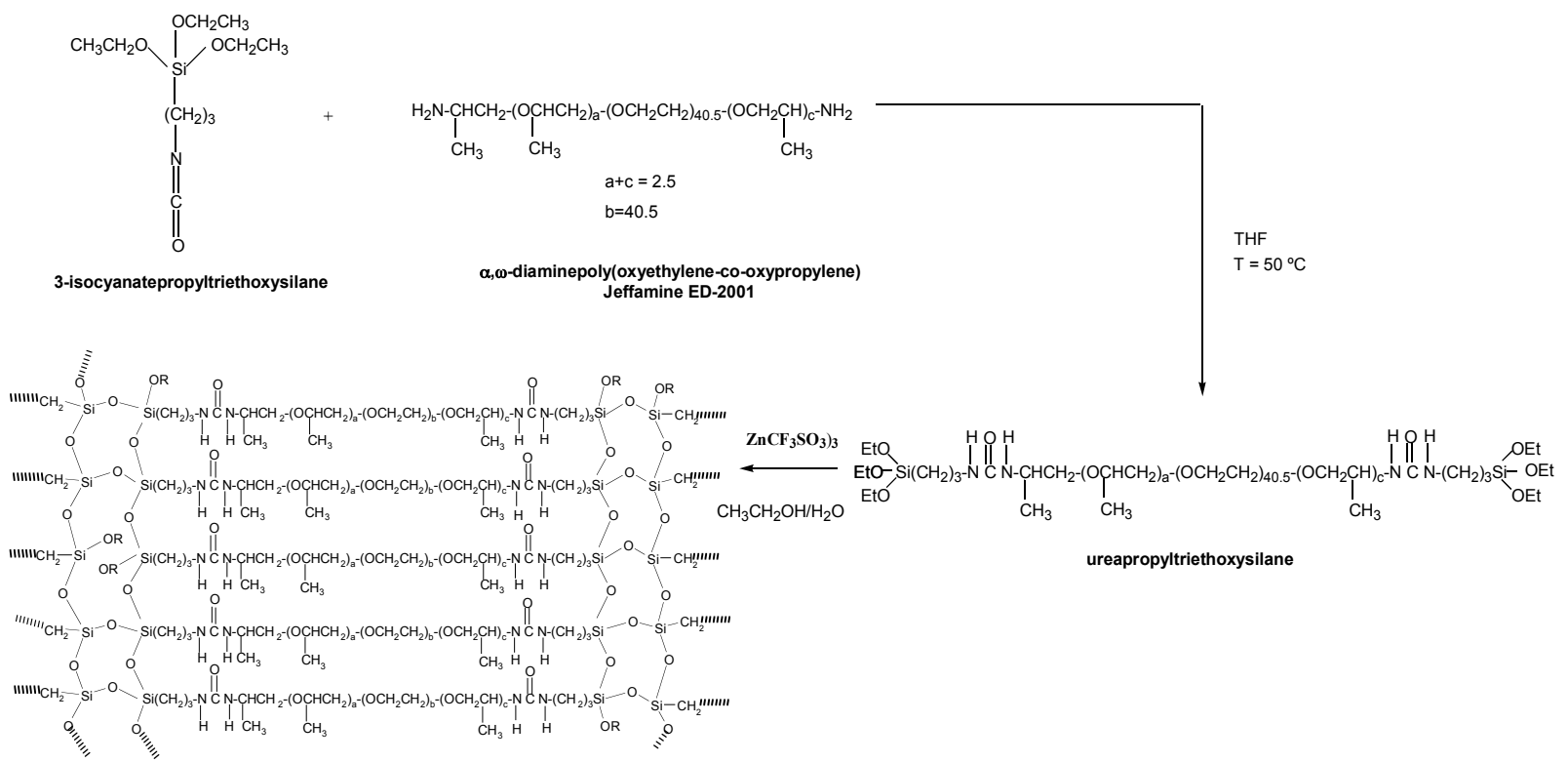

$\left.\mathrm{d}-\mathrm{U}(2000)_{n} \mathrm{ZnCF}_{3} \mathrm{SO}_{3}\right)_{3}$ 
